\title{
Perinatal care in the COVID-19 pandemic: analysis of Brazilian guidelines and protocols
}

Natália Sevilha Stofel 1

https://orcid.org/0000-0002-5928-3477

Daiany Christinelli 2

(iD) https://orcid.org/0000-0002-7204-0920

Rebeca Cardoso de Souza Silva 3

(i) https://orcid.org/0000-0002-4107-2356

Natália Rejane Salim 4

https://orcid.org/0000-0001-7744-8274

Ana Carolina Sartorato Beleza 5

https://orcid.org/0000-0001-6463-8597
Jamile Claro de Castro Bussadori 6

iD https://orcid.org/0000-0002-3048-5593

1-4,6 Departamento de Enfermagem. Universidade Federal de São Carlos. Rodovia Washington Luis s.n. km 235. Caixa Postal 676. São Carlos, SP, Brasil. CEP: 13.565-905. Email: natalia.stofel@ufscar.br

5 Departamento de Fisioterapia. Universidade Federal de São Carlos. São Carlos, SP, Brasil

\begin{abstract}
Objectives: to analyze protocols and direct Brazilian women to prevent perinatal seizures during the COVID-19 pandemic, based on the positive perinatal experience.

Methods: exploratory analysis of document analysis. In the first phase, from April 11 to May 14, in order to search for words with keywords, 402 documents were found. The second phase consisted of reading the set of selected documents and dividing them into categories. The analysis was carried out in light of the guidelines for a positive perinatal experience of the World Health Organization.

Results: as well as directing flow detection phase protocols to mice that show or do not receive COVID-19 symptoms and are being updated with new evidence of systemic evidence. It appears that there are several guidelines for prenatal, partial and puerperium, divergences in some documents for example umbilical cord clamping, skin-to-skin contact, newborn bath.

Conclusions: analyze the permissible conclusions that most recommendations are in line with preconceived notions of positive perinatal experience, but is necessary to adaptation to the Brazilian context.
\end{abstract}

Key words COVID-19, Pregnancy, Maternal and child health, Prenatal care, Guidelines

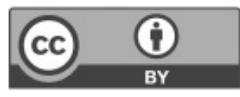




\section{Introduction}

The Ministry of Health (MH), in April 2020, declared all pregnant and puerperal women as being in risk group for COVID-19, because although studies ${ }^{1}$ were not conclusive about the risk of complications in pregnant women, surveys signalize that this population tends to be more sensible and vulnerable to diseases similar to H1N1.2

In the last but one week of May, there were 484 pregnant women with COVID-19 confirmed in the country. The signs and symptoms more frequently presented by pregnant women were cough $(80.6 \%)$, fever $(72.9 \%)$, dyspnea $(62.2 \%)$ and respiratory distress $(50.8 \%) .{ }^{3}$ A study demonstrated that, between January and June 2020, 124 maternal deaths occurred in Brazil, being the country with the highest maternal mortality by Covid-19 in the world. The study highlights weaknesses in the management of healthcare services such as ineffective care, barriers in access to ventilatory support and intensive care. 4

The context of pandemic exposed women to different types of risks and fears, specifically in gestation, delivery and postpartum. These risks involve multiple issues of vulnerability, as well as aspects related to the disease itself, lack of secure information and access to healthcare services, to the hardness in obtaining assistance of quality and based on good practices, 5 being fundamental the reflection about sexual and reproductive rights. The United Nations Population Fund highlighted as an essential action for all countries to protect women's health and rights, as well as putting sexual and reproductive health as fundamental human rights to be assured, which includes the gestation, delivery and puerperium process. In this way, in March 2020, the World Health Organization (WHO) emphasized and published guidelines for assuring better care for pregnant, parturient and puerperal women during the pandemic. 6

The concept of positive experience in childbirth was created by WHO and showed itself to be a great improvement in the field of obstetric care. The concept went under revisions through the decades, and nowadays the elaborated scientific evidences consider not only biological characteristics and characteristics of access to healthcare services, but also thinking the positive childbirth experience as a sexual and reproductive right, with attention to emotional, social and cultural aspects of adult and adolescent women. 7,8

Insofar as a sanitary crisis settles down, the sexual and reproductive rights are increasingly threated. ${ }^{9}$ Yet it is not possible to measure its effects in women's health, it is known that the network of elective and emergency services changed. Thus, the objective of this study was to assess the Brazilian protocols and guidelines concerning perinatal healthcare during COVID-19 pandemic, in the light of the concept of positive childbirth experience.

\section{Methods}

Exploratory study of document analysis of Brazilian guidelines and protocols aiming perinatal attention elaborated to healthcare during COVID-19 pandemic.

The survey was developed between April 11 and May 14, starting with the location of source and selection of documents, using the keywords "COVID-19" AND "perinatalidade" (perinatality) AND "diretrizes" (guidelines) OR "protocolos" (protocols), in Google Scholar website, MS (Ministry of Health) portal and SciELO digital library. The following inclusion criteria were adopted: guidelines or protocols emitted by Brazilian agencies, which were published since the Brazilian government announced community transmission (March 20, 2020), which were related to perinatal healthcare during COVID-19 pandemic. After reading all of the findings (402), seven guidelines and protocols that were entirely available were selected for this study. Subsequently, the collected information was processed and analyzed, 10 with the reading of the seven documents, separated in categories defined posteriorly according to the interest of this study. The analysis was executed by three of the authors, so as the peer review and conference. Each one of the categories was analyzed in the light of positive childbirth experience, as conceived by WHO. 7,8

\section{Results}

Four technical notes were analyzed,11-14 the protocol service of the Brazilian Federation of Gynecology and Obstetrics (FEBRASGO - Portuguese acronym) ${ }^{15}$ and two supplies produced by the portal of good practices of the Oswaldo Cruz Foundation (FIOCRUZ - Portuguese acronym).16,17 Table 1 processes the findings of the categories: COVID-19 testing, adaptation to the social and/or cultural aspects, prenatal following, abortion, type of delivery, labor induction, location of delivery, home delivery, companion in delivery, presence of doulas, offering of liquids during labor, methods of pain relieving, umbilical cord clamping, skin to skin 
contact, breastfeeding in the firsthour, newborn bath, time of discharge for the binomial and breastfeeding at home.

Generally, the documents bring various, sometimes diverging, orientations. In relation to the test for detection of coronavirus, technical notes from the MH (Ministry of Health) do not suggest mass testing for all pregnant women, putting Primary Healthcare (PHC) as responsible for the screening of pregnant women with respiratory symptoms and in labor services, COVID-19 testing only for symptomatic parturients. $12-14$ The document from FEBRASGO15 mentions screening for all pregnant women and companions admitted in labor services. Regarding the need for adaptation to social or cultural aspects where the women reside, this element is placed in the technical note 13,14 which recommends attention from the reference units of vulnerable puerperal women.

Regarding prenatal follow-up, the documents differ in the outflow for women that are suspect or positive-Covid, from those who are asymptomatic. Generally speaking, PHC is regarded as responsible for screening the pregnant women, recommending the delay of elective procedures for 14 days in suspect or confirmed cases, orienting women to perform home isolation and observe the evolution of symptoms. 11,13,14

New screening of pregnant women and companions should be executed in the admission of obstetric services. After screening, women and companions should receive surgical masks and should not walk around the institution. Abortion is only mentioned in the FEBRASGO material that orients expectant behavior for asymptomatic women. In relation to delivery, documents that analyze it are unanimous to state that only confirmed infection by SARS-CoV-2 does not configure indication for labor induction or cesarean section. The situation might be evaluated according to woman's overall status and the evolution of severe respiratory symptoms. ${ }^{12,14-16}$ The water immersion during labor is not indicated, for the virus has been found within feces. 12,15

Regarding labor induction, one of the technical notes from $\mathrm{MH}$ recommends it in case of clinical decompensation, 12 whereas FEBRASGO's 15 document justifies labor induction in order to shorten the time of postpartum hospitalization. Once it is a virus transmitted by droplets, displacement of people in the hospital environment should be restricted, and in this case, the use of pre-partum, partum and postpartum (PPP) rooms for asymptomatic women is recommended in a document. 12 The presence of companions, ensured by Federal Law 11.108, from April 7, 2005, is only assured after negative confirmation for COVID-19,12,14,15,17 the presence of doulas is not recommended by a document, 15 once the assisting team must be reduced, the others do not mention it.

The offering of liquids is recommend by just one document. 15 Two of the documents found,12,15 recommend the use of non-pharmacological methods for pain relieving, highlighting the shower bath.

Umbilical cord clamping was one of the categories in which was found the highest variability, since opportune clamping, 16 going through the one to three minutes wait, 15 according to the vitality of the newborn. ${ }^{17}$ This last document informs:"the clamping of umbilical cord should be executed in the proper moment and following guidelines of the neonatal reanimation program from Brazilian Pediatrics Society. In newborns of gestational age $\geq 34$ weeks that presents adequate breathing and muscle tonus in tension at birth, it is recommended to clamp the umbilical cord from one to three minutes after birth. In newborns with gestational age $<34$ weeks which started to breath or crying and show themselves active, it is indicated to wait 30 to 60 seconds before clamping the umbilical cord. It is recommended the immediate clamping of the cord only in newborns that didn't start to breath nor presented muscle tonus in tension and in case of placental circulation is not intact". 17

The skin-to-skin contact is recommended after hygiene procedures such as bath in bed, using equipment of individual protection such as masks and caps. 14,17 One of the documents 15 contraindicate the skin-to-skin contact to women who tested positive for COVID-19, due to the possible infection of the newborn with fluids and consequent transmission.

Only material elaborated by Fiocruz 16,17 indicates that breastfeeding in the first hour (golden hour) is recommended, since hygiene preventive procedures are taken, 16 and the puerperal woman is in an adequate overall status. ${ }^{17}$ Of the documents that mention or not the need for bathing the newborn right after birth, for the material developed by Fiocruz ${ }^{17}$ there is no need for bathing the newborn, whilst FEBRASGO15 recommends drying and warming of the neonate, followed by bath. The discharge time should be reduced to 24 hours if the binomial is in a good status. ${ }^{12,14}$ Breastfeeding at home is stimulated $12,14-16$ and should be done with the mother using mask and making hand hygiene before and after breastfeeding. 14-16 


\begin{tabular}{|c|c|c|c|c|c|c|c|}
\hline $\begin{array}{l}\text { Document/date of } \\
\text { publication/Category }\end{array}$ & $\begin{array}{l}\text { TN } 07 / 202011 \\
(04 / 08 / 2020)\end{array}$ & $\begin{array}{l}\text { TN 09/202012 } \\
(04 / 10 / 2020)\end{array}$ & $\begin{array}{l}\text { TN } 12 / 202013 \\
(04 / 18 / 2020)\end{array}$ & $\begin{array}{l}\text { Protocol } \\
\text { FEBRASGO15 } \\
(04 / 27 / 2020) \\
\end{array}$ & $\begin{array}{l}\text { TN } 13 / 202014 \\
(05 / 04 / 2020)\end{array}$ & $\begin{array}{c}\text { Gestation and } \\
\text { COVID } 16 \\
(05 / 19 / 2020)\end{array}$ & $\begin{array}{c}\text { NB care in birth } \\
\text { room } 17 \\
(05 / 25 / 2020)\end{array}$ \\
\hline COVID-19 testing & No mention & $\begin{array}{l}\text { Testing in the labor } \\
\text { service only for symp- } \\
\text { tomatic pregnant } \\
\text { women }\end{array}$ & $\begin{array}{l}\text { Testing in the labor } \\
\text { service only for symp- } \\
\text { tomatic pregnant } \\
\text { women }\end{array}$ & $\begin{array}{l}\text { Testing in the labor } \\
\text { service for all preg- } \\
\text { nant women and } \\
\text { companions }\end{array}$ & $\begin{array}{l}\text { Testing in the labor } \\
\text { service only for symp- } \\
\text { tomatic pregnant } \\
\text { women }\end{array}$ & No mention & No mention \\
\hline $\begin{array}{l}\text { Adaptation to the } \\
\text { social/cultural aspects }\end{array}$ & No mention & No mention & No mention & No mention & $\begin{array}{l}\text { Care for all puerperal } \\
\text { women in social vul- } \\
\text { nerability }\end{array}$ & No mention & No mention \\
\hline \multirow[t]{2}{*}{ Prenatal follow-up } & $\begin{array}{l}\text { Continuity in asymp- } \\
\text { tomatic pregnant } \\
\text { women }\end{array}$ & No mention & $\begin{array}{l}\text { Continuity in asymp- } \\
\text { tomatic pregnant } \\
\text { women }\end{array}$ & No mention & $\begin{array}{l}\text { Continuity in asymp- } \\
\text { tomatic pregnant } \\
\text { women }\end{array}$ & No mention & No mention \\
\hline & $\begin{array}{l}\text { Postponement of } \\
\text { elective procedures } \\
\text { for } 14 \text { days to sympto- } \\
\text { matic pregnant } \\
\text { women, morphologi- } \\
\text { cal ultrasound for fol- } \\
\text { low-up of fetal } \\
\text { growth }\end{array}$ & No mention & $\begin{array}{l}\text { Home isolation for } 14 \\
\text { days for symptomatic } \\
\text { pregnant women }\end{array}$ & No mention & $\begin{array}{l}\text { Isolation for } 7 \text { to } 10 \\
\text { days for symptomatic } \\
\text { pregnant women }\end{array}$ & No mention & No mention \\
\hline Abortion & No mention & No mention & No mention & $\begin{array}{l}\text { In asymptomatic } \\
\text { patients with retained } \\
\text { abortion expectant } \\
\text { conduct may be } \\
\text { offered up to } 4 \text { weeks }\end{array}$ & No mention & No mention & No mention \\
\hline Type of delivery & No mention & $\begin{array}{l}\text { SARSCoV-2 is not } \\
\text { indicative for cesare- } \\
\text { an sectio }\end{array}$ & No mention & $\begin{array}{l}\text { Indicates cesarean sec- } \\
\text { tion for women with } \\
\text { severe or critical } \\
\text { symptoms. For the } \\
\text { others, vaginal deli- } \\
\text { very }\end{array}$ & $\begin{array}{l}\text { Indicates cesarean } \\
\text { section for women } \\
\text { with severe or critical } \\
\text { symptoms. For the } \\
\text { others, vaginal deli- } \\
\text { very }\end{array}$ & $\begin{array}{l}\text { Indication of cesarean } \\
\text { section only in cases } \\
\text { of severe respiratory } \\
\text { symptoms }\end{array}$ & No mention \\
\hline
\end{tabular}

$\mathrm{TN}=$ Technical Note; FEBRASGO = Federação Brasileira das Associações de Ginecologia e Obstetrícia (Brazilian Federation of Gynecology and Obstetrics Associations); COVID=coronavirus disease; $\mathrm{NB}=$ newborn. 
Table 1

Categories and recommendations found in analyzed documents about care in childbirth during COVID-19 pandemic. Brazil, 2020.

\begin{tabular}{|c|c|c|c|c|c|c|c|}
\hline $\begin{array}{l}\text { Document/date of } \\
\text { publication/Category }\end{array}$ & $\begin{array}{l}\text { TN 07/202011 } \\
(04 / 08 / 2020)\end{array}$ & $\begin{array}{l}\text { TN 09/202012 } \\
(04 / 10 / 2020)\end{array}$ & $\begin{array}{l}\text { TN 12/202013 } \\
(04 / 18 / 2020)\end{array}$ & $\begin{array}{l}\text { Protocol } \\
\text { FEBRASGO15 } \\
(04 / 27 / 2020)\end{array}$ & $\begin{array}{l}\text { TN 13/202014 } \\
(05 / 04 / 2020)\end{array}$ & $\begin{array}{c}\text { Gestation and } \\
\text { COVID } 16 \\
(05 / 19 / 2020)\end{array}$ & $\begin{array}{c}\text { NB care in birth } \\
\text { room } 17 \\
(05 / 25 / 2020)\end{array}$ \\
\hline
\end{tabular}

No mention

Does not recommend No mention

Does not recommend No mention

No mention

No mention sion sion

Labor induction

No mention

No mention

No mention

No mention

Home birth

Labor companion

No mention
No mention

Labor ind pensation
Does not recommend
home birth for sus-
pect or confirmed
women

$$
\begin{aligned}
& \text { Recommends PPP } \\
& \text { rooms for confirmed } \\
& \text { or suspect pregnant } \\
& \text { women }
\end{aligned}
$$

After negative confir- No mention

No mention

No mention
No mention

mation of Covid-19

for the screening, a

companion wearing

mask is allowed

delivery for all preg-

nant women

Delivery and labor follow up in location with maternal-fetus management

Delivery and labor fol-

No mention the pregnant women

is in adequate clinical

conditions

No mention

No mention

TN= Technical Note; FEBRASGO = Federação Brasileira das Associações de Ginecologia e Obstetrícia (Brazilian Federation of Gynecology and Obstetrics Associations); CoVID=coronavirus disease; $\underset{\omega}{\tilde{H}} \mathrm{NB}=$ newborn. 


\begin{tabular}{|c|c|c|c|c|c|c|c|}
\hline $\begin{array}{l}\text { Document/date of } \\
\text { publication/Category }\end{array}$ & $\begin{array}{l}\text { TN 07/202011 } \\
(04 / 08 / 2020)\end{array}$ & $\begin{array}{l}\text { TN 09/202012 } \\
(04 / 10 / 2020)\end{array}$ & $\begin{array}{l}\text { TN } 12 / 202013 \\
(04 / 18 / 2020)\end{array}$ & $\begin{array}{l}\text { Protocol } \\
\text { FEBRASGO15 } \\
(04 / 27 / 2020)\end{array}$ & $\begin{array}{l}\text { TN } 13 / 202014 \\
(05 / 04 / 2020)\end{array}$ & $\begin{array}{l}\text { Gestation and } \\
\text { COVID16 } \\
(05 / 19 / 2020)\end{array}$ & $\begin{array}{c}\text { NB care in birth } \\
\text { room } 17 \\
(05 / 25 / 2020)\end{array}$ \\
\hline Presence of doulas & No mention & No mention & No mention & Does not recommend & No mention & No mention & No mention \\
\hline $\begin{array}{l}\text { Offering of liquids du- } \\
\text { ring labor }\end{array}$ & No mention & No mention & No mention & No mention & Allowed & No mention & No mention \\
\hline Pain relieving methods & No mention & Recommended & No mention & Recommended & No mention & No mention & No mention \\
\hline Umbilical cord clamping & Inconclusive & No mention & No mention & Wait 1 to 3 minutes & No mention & Opportune clamping & $\begin{array}{l}\text { Variable according to } \\
\text { the NB's vitality }\end{array}$ \\
\hline Skin-to-skin contact & No mention & No mention & No mention & $\begin{array}{l}\text { Not recommended } \\
\text { skin-to-skin contact to } \\
\text { patients with COVID- } \\
19\end{array}$ & $\begin{array}{l}\text { Hygiene before and } \\
\text { after contact with the } \\
\text { NB, including bath in } \\
\text { the bed, use of caps. }\end{array}$ & No mention & $\begin{array}{l}\text { Hygiene before and } \\
\text { after contact with the } \\
N B \text {, including bath in } \\
\text { the bed, use of caps. }\end{array}$ \\
\hline $\begin{array}{l}\text { Breastfeeding in the first } \\
\text { hour }\end{array}$ & No mention & No mention & No mention & No mention & No mention & $\begin{array}{l}\text { Recommended since it } \\
\text { is according to the } \\
\text { necessary preventive } \\
\text { procedures. }\end{array}$ & $\begin{array}{l}\text { Puerperal women in } \\
\text { adequate overall sta- } \\
\text { tus should maintain } \\
\text { breastfeeding follow- } \\
\text { ing necessary protec- } \\
\text { tion procedures }\end{array}$ \\
\hline Newborn's bath & No mention & No mention & No mention & $\begin{array}{l}\text { Drying and warming } \\
\text { of NB, followed by } \\
\text { bath }\end{array}$ & No mention & No mention & $\begin{array}{l}\text { NB should be dried up } \\
\text { with intact umbilical } \\
\text { cord, bath right after } \\
\text { birth not necessary }\end{array}$ \\
\hline
\end{tabular}

TN= Technical Note; FEBRASGO = Federação Brasileira das Associações de Ginecologia e Obstetrícia (Brazilian Federation of Gynecology and Obstetrics Associations); COVID=coronavirus disease; $\mathrm{NB}=$ newborn. 
Categories and recommendations found in analyzed documents about care in childbirth during COVID-19 pandemic. Brazil, 2020.

\begin{tabular}{|c|c|c|c|c|c|c|c|}
\hline $\begin{array}{l}\text { Document/date of } \\
\text { publication/Category }\end{array}$ & $\begin{array}{l}\text { TN } 07 / 202011 \\
(04 / 08 / 2020)\end{array}$ & $\begin{array}{l}\text { TN 09/202012 } \\
(04 / 10 / 2020)\end{array}$ & $\begin{array}{l}\text { TN } 12 / 2020^{13} \\
(04 / 18 / 2020)\end{array}$ & $\begin{array}{l}\text { Protocol } \\
\text { FEBRASGO15 } \\
(04 / 27 / 2020)\end{array}$ & $\begin{array}{l}\text { TN } 13 / 2020^{14} \\
(05 / 04 / 2020)\end{array}$ & $\begin{array}{c}\text { Gestation and } \\
\text { COVID } 16 \\
(05 / 19 / 2020)\end{array}$ & $\begin{array}{c}\text { NB care in birth } \\
\text { room } 17 \\
(05 / 25 / 2020)\end{array}$ \\
\hline $\begin{array}{l}\text { Time of binomial's dis- } \\
\text { charge }\end{array}$ & No mention & $\begin{array}{l}24 \text { hours for healthy } \\
\text { binomial }\end{array}$ & No mention & - & $\begin{array}{l}24 \text { hours for healthy } \\
\text { binomial }\end{array}$ & No mention & No mention \\
\hline Breastfeeding at home & No mention & Recommended & No mention & $\begin{array}{l}\text { Recommends use of } \\
\text { mask and hand } \\
\text { hygiene before and } \\
\text { after }\end{array}$ & $\begin{array}{l}\text { Recommends use of } \\
\text { mask and hand } \\
\text { hygiene before and } \\
\text { after }\end{array}$ & $\begin{array}{l}\text { Recommends use of } \\
\text { mask and hand } \\
\text { hygiene before and } \\
\text { after }\end{array}$ & No mention \\
\hline
\end{tabular}

TN= Technical Note; FEBRASGO = Federação Brasileira das Associações de Ginecologia e Obstetrícia (Brazilian Federation of Gynecology and Obstetrics Associations); COVID=coronavirus disease; $\mathrm{NB}=$ newborn. 


\section{Discussion}

Since pregnant and puerperal women were included in the risk group for COVID-19, MH and other Brazilian agencies have been emitting service protocols in attempt of establishing fluxes for prevention and treatment. For it is a new disease, the speed of publication and change of protocols has been requiring fast adaptation from health professionals and services, which perhaps not always will come together with practices based on evidences, on humanization and on women's rights. ${ }^{18}$

The results of this analysis show differing in the execution or not of tests for detection of coronavirus in pregnant women that present or not respiratory symptoms of the disease; such fact is anchored in the time of onset of COVID-19 symptoms. However, more than $80 \%$ of women with COVID-19 which are admitted into childbirth care services are asymptomatic. 19

The care in the pregnancy-puerperium cycle in Brazilian context already had weaknesses before the pandemics, characterized by the excessive use of hard technologies and medicalization of women's bodies, of labor and birth and institutional racism. High rates of cesarean sections, 20,21 frequent use of episiotomies 22 and obstetric violence highlighted by racism 23 are consequences of this scenario.

The power relations present in the control of pregnancy-puerperal cycle are more tensioned during the sanitary crisis, with severe threats to reproductive and sexual rights, so that the COVID19 pandemic might be a risk factor for obstetric violence. $6,24,25$

Furthermore, for a positive childbirth experience, the social determinants of health are key factors, 7,8 as well as for the understanding of mortality of pregnant and puerperal woman by COVID-19, a survey demonstrated that eight out of ten pregnant and puerperal women which died of coronavirus in the world were Brazilian and the majority of them were non-white, ${ }^{4}$ and an English series evidenced that black women with morbidities such as obesity, hypertension and diabetes have more probability of presenting COVID-19.26

When considering the profile of maternal mortality in Brazil, in which morbidities such as hypertension (eclampsia and pre-eclampsia) stands out as the main causes, ${ }^{27}$ delaying prenatal care in 14 days for women with coronavirus symptoms, as protocols suggest, can be determinant to a unfavorable maternal and neonatal outcome, since, however the prenatal coverage in Brazil is nearly universal, there is no completeness in the actions, such as, for example, the execution of complementary exams that don't reach $70 \%$ of all pregnant women. 28

It is perceived in the $\mathrm{MH}$ guidelines the responsibility of PHC as a manager of mother-and-child care. The Unified Health System has been standing out, in this pandemic situation, the only alternative for the majority of population, being necessary, thus, investments in the system, as well as in the technoassistance model of Family Health Strategies, in order to assure the access to prenatal and puerperal quality care. 29

The study showed protocols aligned to international recommendations, ${ }^{30}$ attempting to ensure women's autonomy, as well as demedicalization of the perinatal cycle. In this crisis, women's rights, hardly achieved over long years of improvements and expressed in public policies, are severely threaten.

More than the propagation of protocols of flux, actions that follow the management indicators of adequate practices which support positive experience in childbirth are necessary. The daily findings of scientific researches should be considered and adapted to the sociodemographic reality of each territory. It is necessary the regulation and organization of mother-and-child healthcare network, in order to ensure access, quality, safety and continuity in care for women and newborns with or without COVID-19.

\section{Author's contribution}

Stofel NS and Christinelli D participated in the concept and design of the study, data analysis and acquisition. Silva RCS participated in data analysis and acquisition. Salim NR, Beleza ACS and Bussadori JCC participated in data interpretation and writing of the manuscript. All authors participated in data interpretation, writing and critical revision of the manuscript and approved the final version of the article. 


\section{References}

1. Chen H, Guo J, Wang C, Luo F, Yu X, Zhang W, Li J, Zhao D, Xu D, Gong Q, Liao J, Yang H, Hou W, Zhang Y. Clinical characteristics and intrauterine vertical transmission potential of COVID-19 infection in nine pregnant women: a retrospective review of medical records. Lancet. 2020; 395 (10226):809-15. Available from https://www.thelancet.com/journals/lancet/article/PIIS0140 $-6736(20) 30360-3 /$ fulltext

2. Brasil. Ministério da Saúde. Secretaria de Vigilância em Saúde. Boletim Epidemiológico número 7. [acesso em 30 jul 2020]. Disponível em: https://central3.to.gov.br/ arquivo/505115/.

3. Brasil. Ministério da Saúde. Boletim Epidemiológico Especial COE-COVID-19. Secretaria de Vigilância em Saúde. [acesso 23 mai 2020]. Disponível em:https://www.saude.gov.br/images/pdf/2020/May/29/202 0-05-25---BEE17---Boletim-do-COE.pdf

4. Takemoto MLS, Menezes MO, Andreucci CB, NakamuraPereira M, Amorim MMR, Katz L,Knobel R. The tragedy of COVID-19 in Brazil: 124 maternal deaths and counting. Int J Gynaecol Obstet. 2020. [acesso 15 ago 2020]; 9(1) Disponível em: https://www.arca.fiocruz.br/handle/icict/ 42199.

5. Almeida MO, Portugal TM, Assis TJCF. Gestantes e COVID-19: isolamento como fator de impacto físico e psíquico. Rev Bras Saúde Mater Infant. 2020; 20 ( 2 ): 599602.

6. WHO (World Health Organization). Pregnancy, childbirth and COVID-19.2020 [acesso em 18 ago 2020]. Disponível em: https://www.who.int/emergencies/diseases/novel-coronavirus-2019/question-and-answers-

hub.https://brazil.unfpa.org/pt-br/pandemia-de-covid-19

7. WHO (World Health Organization). WHO recommendations: on antenatal care for a positive pregnancy experience. [acesso em 18 de out de 2020]. Disponível em https://www.who.int/reproductivehealth/publications/mater nal_perinatal_health/anc-positive-pregnancyexperience/en/.

8. WHO (World Health Organization). WHO recommendations: intrapartum care for a positive childbirth experience. [acesso em 18 de out de 2020]. Disponível em https://www.who.int/reproductivehealth/publications/intrapartum-care-guidelines/en/.

9. UNFPA Brasil. COVID-19: Um olhar para gênero. Promoção da saúde e dos direitos sexuais e reprodutivos e promoção da igualdade de gênero. Março, 2020. Disponível em: https://www.unfpa.org/sites/default/files/resourcepdf/Portoguese-covid19_olhar_genero.pdf.

10. Cellard A. A análise documental. In: Poupar TJ. et al. A pesquisa qualitativa: enfoques epistemológicos e metodológicos. Petrópolis (RJ): Vozes; 2008. p. 295-316.

11. Brasil. Ministério da Saúde. Secretaria de Atenção Primária à Saúde. Departamento de Ações Programáticas Estratégicas. Coordenação-Geral de Ciclos da Vida. Coordenação de Saúde das Mulheres. Nota Técnica ${ }^{\circ}$ 7/2020-COSMU/CGCIVI/DAPES/SAPS/MS - Atenção às Gestantes no Contexto da Infecção COVID-19 Causada pelo novo Coronavírus (SARS-CoV-2). Brasília, DF; Abr.; 2020 .
12. Brasil. Ministério da Saúde. Secretaria de Atenção Primária à Saúde. Departamento de Ações Programáticas Estratégicas. Coordenação-Geral de Ciclos da Vida. Coordenação de Saúde das Mulheres. Nota Técnica $n^{\circ}$ 9/2020 - COSMU/CGCIVI/DAPES/SAPS/MS Recomendações para o Trabalho de Parto, Parto e Puerpério durante a pandemia da COVID-19. Brasília, DF; 2020.

13. Brasil. Ministério da Saúde. Secretaria de Atenção Primária à Saúde. Departamento de Ações Programáticas Estratégicas. Coordenação-Geral de Ciclos da Vida. Coordenação da Saúde da Mulher.Nota Técnica $\mathrm{N}^{\circ}$ 12/2020-COSMU/CGCIVI/DAPES/SAPS/M. Infecção COVID-19 e os riscos às mulheres no ciclo gravídico-puerperal.Brasília, DF; Abr. 2020.

14. Brasil. Ministério da Saúde. Secretaria de Atenção Primária à Saúde. Departamento de Ações Programáticas Estratégicas. Coordenação-Geral de Ciclos da Vida. Coordenação de Saúde das Mulheres.Nota Técnica $n^{\circ}$ 13/2020 - COSMU/CGCIVI/DAPES/SAPS/MSRecomendações acerca da Atenção Puerperal, Alta Segura e Contracepção durante a pandemia da COVID-19. Brasília, DF; Mai. 2020

15. FEBRASGO(Federação Brasileira das Associações de Ginecologia e Obstetrícia). COVID-19: Orientações da Febrasgo para atendimento na gestação, parto, puerpério. [acesso 10 mai 2020].Disponível em: https://portaldeboaspraticas.iff.fiocruz.br/atencao-mulher/covid-19-orientacoes-da-febrasgo-para-avaliacao-e-tratamento-ambulatorial-de-gestantes/.

16. Brasil. Ministério da Saúde. Portal de Boas Práticas em Saúde da Mulher, da Criança e do Adolescente Coronavírus e Gestação. Março 2020. [acesso 28 out 2020]. Disponível em: https://portaldeboaspraticas.iff.fiocruz.br/ atencao-mulher/coronavirus-gestacao/.

17. Brasil. Ministério da Saúde. Portal de Boas Práticas em Saúde da Mulher, da Criança e do Adolescente - Atenção ao Recém-nascido em tempos da pandemia de COVID-19: Recomendações para a Sala de Parto. Março 2020. [acesso 28 out 2020]. Disponível em: https://portaldeboaspraticas. iff.fiocruz.br/atencao-recem-nascido/atencao-ao-recemnascido-em-tempos-da-pandemia-de-covid-19-recomendacoes-para-a-sala-de-parto/.

18. Estrela FM, Silva KKA, Cruz, Moniky AG, Pereira N. Gestantes no contexto da pandemia da Covid-19: reflexões e desafios. Physis: Rev Saúde Coletiva.2020; 30 (2):1-5.

19. Khalil A, Hill R, Ladhani S, Pattisson K, O'brien P. SARSCoV-2 in pregnancy woman are only the tip of iceberg. AmJ Obstet Gynecol. 2020. [acesso 21 jul 2020]. Disponível em: https://www.ajog.org/article/S0002-9378(20)30529-9/pdf.

20. Diniz SG. Gênero, saúde materna e o paradoxo perinatal. J Hum Growth Dev. 2009; 19 (2): 313-26.

21. Leal MC, Szwarcwald CL, Almeida PVB, Aquino, EML, Barreto ML, Barros F, Victora C. Saúde reprodutiva, materna, neonatal e infantil nos 30 anos do Sistema Único de Saúde (SUS). Ciênc Saúde Coletiva. 2018; 23 (6): 191528.

22. Lopes GC, Gonçalves AC, Gouveia HG, Armellini CJ. Atenção ao parto e nascimento em hospital universitário: 
comparação de práticas desenvolvidas após Rede Cegonha. Rev Latino-Am Enferm. 2019; 27: e3139.

23. Leal MC, Gama SGN, Pereira APE, Pacheco VE, Do Carmo CN, Santos RV. A cor da dor: iniquidades raciais na atenção pré-natal e ao parto no Brasil. Cad Saúde Pública. 2017; 33 (Supl.1): e00078816.

24. Insfran F, Muniz AGCR. Maternagem e Covid-19: desigualdade de gênero sendo reafirmada na pandemia. Diversitates IntJ. 2020; 12 (2): 26-47.

25. Sentidos do Nascer. Recomendação para a assistência ao parto e nascimento em tempos de pandemia de Covid-19. em defesa dos direitos das mulheres e dos bebês. [online]. 2020. [acesso 11 ago 2020]. Disponível em: http://www.sentidosdonascer.org.

26. Knight M, Bunch K, VousdenN, Morris E, Simpson N, Gale C, O'Brien P, Quigley M, Brocklehurst P, Kurinczuk P. Characteristics and outcomes of pregnant women admitted to hospital with confirmed SARS-CoV-2 infection in UK national population based cohort study. BMJ. 2020; 369: $\mathrm{m} 2107$.
27. Silva BGC, Lima NP, Silva SG, Antúnez SF, Seerig LM, Restrepo-Méndez MC, Wehrmeister FC. Mortalidade materna no Brasil no período de 2001 a 2012: tendência temporal e diferenças regionais. Rev Bras Epidemiol. 2016; 19(3): 484-93.

28. Tomasi E, Fernandes PAA, Fischer T, Siqueira FS, Silveira DS, Thumé E, Facchini LA. Qualidade da atenção pré-natal na rede básica de saúde do Brasil: indicadores e desigualdades sociais. Cad Saúde Pública. 2017; 33(3): e00195815.

29. Facchini LA. COVID-19: nocaute do neoliberalismo? Será possível fortalecer os princípios históricos do SUS e da APS em meio à pandemia?APS Rev. 2020; 2 (1): 3-10.

30. NarangK, Ibirogba ER, Elrefaei A,Trad ATA, Theiler R, Nomura R, Picone O, Kilby M, Escuriet M, Suy A, Carreras E, Tonni G, Ruano R. SARS-CoV-2 in Pregnancy: a Comprehensive Summary of Current Guidelines. J Clin Med. 2020; 9 (5): 1521

Received on September 23, 2020

Approved on October 30, 2020 